\title{
NEGLIGENT MISREPRESENTATIONS UNDER RULE 10b-5
}

Glause (2) of SEC Rule 10b-5, promulgated under section 10(b) of the Securities Exchange Act of 1934,1 proscribes the making of false or misleading statements in connection with the purchase or sale of securities. ${ }^{2}$ Neither the Rule nor section $10(\mathrm{~b})$ mentions civil liability, but the courts have uniformly inferred a private remedy under the Rule. ${ }^{3}$ There is, however, no agreement on what the substantive elements of a 10b-5(2) private action, particularly with respect to the elements of scienter and reliance, should be. ${ }^{4}$ The primary problem results from the ambiguity of the Rule's language. In resolving this ambiguity, reference must be made to one or more rational guidelines, but the absence of express legislative directions regarding 10b-5 makes the choice and application of such guidelines difficult. Moreover, attempts to formulate a scheme of recovery under 10b-5(2) must consider the implications of a prior, congressionally delineated civil remedy whose scope potentially overlaps that of $10 \mathrm{~b}-5(2)$. This comment suggests what the substantive elements of the $10 \mathrm{~b}-5(2)$ misrepresentation action $^{5}$ should be in light of the overall goals of federal securities legislation. ${ }^{6}$

148 Stat. 881 (1934), 15 U.S.C. \& 78j(b) (1958).

2 The Rule is called into play only where the proscribed deed is perpetrated "directly or indirectly, by the use of any means or instrumentality of interstate commerce or of the mails or of any facility of any national securities exchange . . . "The proscriptions of the Rule are embodied in three sub-paragraphs which respectively make it "unlawful": "(1) to employ any device, scheme or artifice to defraud, or (2) to make any untrue statement of a material fact or to omit to state a material fact necessary in order to make the statements made, in the light of the circumstances under which they were made, not misleading, or (3) to engage in any act, practice or course of business which operates or would operate as a fraud or deceit upon any person, in connection with the purchase or sale of any security." 17 C.F.R. $\S 240.10 \mathrm{~b}-5$ (1949).

3 See, e.g., Kohler v. Kohler Co., 319 F.2d 634 (7th Cir. 1963); McClure v. Borne Chem. Co., 292 F.2d 824 (3d Cir.), cert. denied, 368 U.S. 939 (1961); Connelly v. Balkwill, 279 F.2d 685 (6th Cir. 1960); Fratt v. Robinson, 203 F.2d 627 (9th Cir. 1953); Fischman v. Raytheon Mfg. Co., 188 F.2d 783 (2d Cir. 195I); Kardon v. National Gypsum Corp., 69 F. Supp. 513 (E.D. Pa. 1946).

4 See, e.g., the reference in Barnett v. Anaconda Co., 238 F. Supp. 766 (S.D.N.Y. 1965) to the "... rather muddied state of the law with respect to the elements of a claim under ... Rule 10b-5..." Id. at 774 .

5 This comment will not focus directly on the other clauses of $10 \mathrm{~b}-5$, or on the problem of complete non-disclosure. See notes 9,11 \& 13 infra.

6 Within a short time before this comment went to press, several student treatments of the topic appeared. Comment, 74 YALE L.J. 658 (1965); Note, 63 Mick. L. REv. 1070 
There are three basic types of conduct on the part of a buyer or seller of securities which fall within the ambit of $10 \mathrm{~b}-5$. First, affurmative misrepresentation: the defendant makes a statement of material fact which is false. ${ }^{7}$ Second, half-truths: the defendant makes a number of statements which are themselves true, but he omits a material fact or facts so that the true statements in context are misleading. ${ }^{8}$ Third, complete omission: the defendant makes no representations of material fact, but omits to state facts which would influence the plaintiff in his actions. ${ }^{9}$

(1965). (The latter is essentially an expanded case note on Trussell v. United Underwriters, Ltd., 228 F. Supp. 757 (D. Colo. 1964); see text accompanying note 48 infra.)

T Murphy v. Cady, 30 F. Supp. 466 (D. Me. 1939), aff'd, 113 F.2d 988 (1st Cir.), cert. denied, 31 I U.S. 705 (1940), held that a representation that a corporation's affairs were being managed by someone who was not the true manager constituted a material misrepresentation under the similar language of section 12(2) of the Securities Act of 1933. See note 26 infra. Compare United States v. Schaefer, 299 F.2d 625 (7th Cir. 1962) (criminal prosecution under 17(a) of the 1933 Act, see note 26 infra), involving false representations to investors that the U.S. Navy and several large firms had made sub. stantial bids for the defendant's invention.

8 See, e.g., Texas Continental Life Ins. Co. v. Bankers Bond Co., 187 F. Supp. 14 (W.D. Ky. 1960), rev'd on fact issue sub nom. Texas Continental Life Ins. Co. v. Dunne, 307 F.2d 242 (6th Cir. 1962), where defendant, in reselling municipal bonds to plaintiff, allegedly did not tell buyer that the bonds had been issued on credit by the municipality, and that the resultant obligation on the note was payable by return of the outstanding bonds in lieu of cash; Royal Air Properties, Inc. v. Smith, 312 F.2d 210 (9th Cir. 1962), where defendant-seller allegedly omitted mention of outstanding mortgages on corporate property in his estimation of profits and rate of return to plaintiff-buyer.

9 See, e.g., In re Cady, Roberts \& Co., 40 S.E.C. 907 (1961), where a seller of securities on the open market made no mention of material inside information which had come to his attention and which assured the subsequent decrease in value of the stock sold. Although Cady, Roberts was not a private action, the fact situation presents a striking illustration of the potential scope of the prohibitions involved. See generally, Comment, Insider Liability Under Securities Exchange Act Rule 10b-5: The Cady, Roberts Doctrine, 30 U. CHI. L. REv. 121 (1962). This comment will not treat the different problems of fact and interpretation raised by the question of complete omission. It should be noted, however, that liability under $10 \mathrm{~b}-5$ for complete silence, or non-disclosure, will depend on the court's view of what circumstances impose a duty to speak: "[T] to speak which is implicit in Rule X-10B-5 arises in those circumstances where a fiduciary or quasi-fiduciary relation exists, where confidence is reposed or influence acquired, where there is a justifiable expectancy of disclosure or reliance upon the superior knowledge of another and in like circumstances." Connelly v. Balkwill, 174 F. Supp. 49, 59 (N.D. Ohio 1959), aff'd, 279 F.2d 685 (6th Cir. 1960). The doctrine was phrased somewhat differently in Cady, Roberts, supra at 912: "Analytically, the obligation to disclose rests on two principal elements; first, the existence of a relationship giving access, directly or indirectly, to information intended to be available only for a corporate purpose and not for the personal benefit of anyone, and second, the inherent unfairness involved where a party takes advantage of such information knowing it is unavailable to those with whom he is dealing." See generally Ruder, Pitfalls in the Development of a Federal Law of Corporations by Implication Through Rule 10b-5, 59 Nw. U.L. REv. 185 (1964); Joseph, Civil 
Unfortunately, these separate types of conduct do not fall neatly within the separate sections of the Rule, for there is considerable overlap if the language of each sub-section is taken literally. Thus, there is a question whether a defendant who has either made an affirmative misrepresentation or spoken a half-truth, both of which clearly fall within clause (2), may nevertheless be sued under clause (3). ${ }^{10}$

This ambiguity is significant because the clauses suggest varying substantive requirements. Clause (1), by use of the phrase "to defraud," implies a requirement of intent, 11 whereas clause (2) implies no such requirement, and the language of clause (3) ("would operate as a fraud") emphasizes the effect of the conduct rather than the actor's state of mind. While a misrepresentation, either by way of complete falsehood or half-truth, arguably constitutes an "act" or "practice" which may "operate as a fraud" upon the plaintiff within the language of clause (3), ${ }^{12}$ with whatever easing of proof may follow, such a construction would in effect make clause (2) mere surplusage. Yet because clause (2) is the most detailed of the three clauses in its description of the type of conduct proscribed it should be the principal enforcement clause for such conduct. Clause (3) in this scheme should relate primarily to complete non-disclosures ${ }^{13}$ as its language "operates or would operate"

Liability Under Rule 10b-5-A Reply, 59 Nw. U.L. REv. 171 (1964); Ruder, Civil Liability Under Rule 10b-5: Judicial Revision of Legislative Intent?, 57 Nw. U.L. REv. 627 (1963); Latty, The Aggrieved Buyer or Seller or Holder of Shares in a Close Corporation Under the S.E.C. Statutes, 18 LaW \& Contemp. Prob. 505 (1953); Note, 42 VA. L. Rev. 537, 546-64 (1956); Note, 40 MinN. L. Rev. 62 (1955); Note, 14 U. GHI. L. REv. 471 (1947).

10 The same problem is present with regard to section 17(a) of the 1933 Act, the sub-clauses of which are nearly parallel to those of $10 \mathrm{~b}-5$. See, e.g., United States v. Schaefer, 299 F.2d 625 (7th Cir. 1962) (reversing conviction on other grounds), where affirmative misrepresentations were deemed part of a "scheme to defraud" under clause $17 \mathrm{a}(1)$.

11 Cf. Section 8(a)(3) of the National Labor Relations Act, 49 Stat. 452 (1935), as amended, 29 U.S.C. $\$ 158$ (a)(3) (1958), which bars certain employer actions "to encourage or discourage" union membership, and which has been construed to demand intent or motivation on the employer's part. See e.g., Phelps Dodge Corp. v. NLRB, 313 U.S. 177 (1941). But see Comment, 32 U. CHI. L. Rev. 124, 127-31 (1964).

12 See, e.g., Speed v. Transamerica Corp., 99 F. Supp. 808 (D. Del. 1951). See note 14 infra.

13 At least one court has suggested that "silence cannot be deemed to be the employment of 'any device, scheme or artifice' contemplated by the interdiction of . . . [clause (I)]." Joseph v. Farnsworth Radio \& Television Corp., 99 F. Supp. 701, 706 (S.D.N.Y. 1951), aff'd, 198 F.2d 883 (2d Cir. 1952). Clause (3), however, has been construed as sufficiently broad to encompass complete silence where the so-called "insider's duty to disclose" is violated. See note 9 supra; see also Comment, 32 Texas L. Rev. 197, 200 (1953). 
suggests. Granted the importance of these distinctions for proper implementation of the Rule, however, few courts have drawn them. ${ }^{14}$

Clause (2) should, therefore, govern $10 \mathrm{~b}-5$ actions based on affirmative misrepresentations or half-truths. The problem then becomes whether the plaintiff may recover simply on proof that the misleading statement was made or whether he must establish some degree of fault on the defendant's part. The three basic alternatives are: ${ }^{15}$ (1) absolute liability -the fact that the statements made were false or misleading is sufficient to establish liability regardless of the defendant's state of mind; (2) intentional liability-the false or misleading statements must have been made knowingly or with intent to mislead; (3) negligence liability-the defendant will not be liable if he was unaware of the deception and could not have cured it by the exercise of reasonable care. ${ }^{16}$

14 This distinction will have no practical consequences as long as the courts view the Rule as a whole. In Speed v. Transamerica Corp., 99 F. Supp. 808 (D. Del. 1951), for example, the court ruled that defendants' failure to disclose to the seller-plaintiffs the corporation's increased earnings and inventory valuations before purchasing plaintiffs' stock violated all three clauses. The court styled the defendants' failure to disclose as an "implied misrepresentation" constituting "an untrue statement of a material fact within the meaning of the governing rule." The defendants, however, had apparently made certain material statements to the plaintiffs to induce the sale, so that the offense was a half-truth, clearly within the ambit of clause (2). There was, therefore, no need for the court's characterization of the omission as an "implied misrepresentation." Also, plaintiffs had established the defendants' intent to defraud. Thus the opinion seems more the result of an abundance of resources than keen analysis. See also List v. Fashion Park, Inc., 340 F.2d 457, 462 (2d Gir. 1965), where the court conceded that complete silence may not violate clauses (I) or (2) but went on to say: "[W] fail to see that it makes any difference which clause of Rule $10 \mathrm{~b}-5$ is relied on by plaintiff, and no reason for requiring a choice here has been pointed out to us." (Emphasis added.) Trussell v. United Underwriters, Ltd., 228 F. Supp. 757 (D. Colo. 1964), exemplifies a more discerning approach by suggesting that where complete non-disclosure is the crux of the alleged offense, the plaintiff's claim cannot be based on clause (2), some affirmative statement being required by that clause. Accord, Cochran v. Channing Corp., 211 F. Supp. 239, 243 (S.D.N.Y. 1962). See also In re Cady, Roberts \&: Co., 40 S.E.C. 907,913 nn.19 \& 20 (1961). This comment will proceed on the assumption that the clauses should stand alone and encompass generally different spheres of conduct.

15 These formulations are not intended to be exhaustive but rather to indicate the general directions of interpretation possible along a continuum ranging from complete subjective innocence to utter subjective intent. Thus, for instance, characterizations such as "reckless disregard of the truth or falsity of the statements made" or "constructive knowledge based on the totality of defendant's action" might be included either under negligent or intentional liability. But see Trussell v. United Underwriters, Ltd., supra note 14. A recent student comment on this problem distinguished only two broad alternatives reflecting this continuum-scienter-negligence and absolute liability-and opted for the former. Note, 63 Mich. L. REv. 1070 (1965).

10 All three alternatives involve reasonable constructions of clause (2). Clearly, absolute liability would be in accord with the language of the clause, which makes no mention of knowledge or intent. On the other hand, the right of action involved is a creature of judicial inference, and the courts may define it by reading into the action 
Since nothing in the history of $10 \mathrm{~b}-5$ illuminates the problem of what substantive elements must be proven, both the general objectives of federal securities legislation, especially as reflected in those provisions of section 12(2) of the 1933 Act which closely parallels the language of $10 \mathrm{~b}-5(2)$, and the common law background should be highly relevant in determining the proper interpretation of the Rule. Although no evidence exists that Congress ever considered a private action under section 10(b) of the 1934 Act, ${ }^{17}$ the implication of a civil right of action does not depend so much on the existence of affirmative evidence of congressional intent as.it does on the absence of evidence that Congress did not so intend. ${ }^{18}$ Thus, while the basis for an implied action is firm, as a matter of judicial doctrine, "legislative intent" as applied to the elements of the 10b-5 action is somewhat fictive. Hence the whole pattern of relevant securities law must be considered and as the Supreme Court has recently indicated, "Congress intended ... securities legislation 'enacted for the purpose of avoiding frauds' [to be construed] not technically and restrictively but rather flexibly to effectuate its remedial purposes."19

elements not expressly contained in the language of the Rule, such as negligence or scienter limitations, in accord with their notion of legislative intent. The courts have professed to undertake such a process of implication, e.g., with section 8(a)(3) of the National Labor Relations Act. See note 11 supra.

17 See, e.g., Joseph, supra note 9, at 174; 74 YALE L.J. 658, 660 (1965); III Loss, SECURITIES REGULATION 1757-59 (2d ed. 1961).

18 "Implied rights of action are not contingent upon statutory language which affirmatively indicate that they are intended. On the contrary, they are implied unless the legislation evidences a contrary intention." Brown v. Bullock, 194 F. Supp. 207, 224 (S.D.N.Y.), aff'd, 294 F.2d 415 (2d Cir. 1961) (implying a civil right of action under section 37 of the Investment Advisers Act of 1940). This view is generally applied to the "tort theory" of implied liability, which proceeds on the principle that where a statute is enacted for the protection of a given class of persons, a member of that class may recover for injuries received as a result of violation of the enactment. The principle is embodied in section 286 of the Restatement of Torts, which has been recognized as an authoritative formulation of the rationale in most jurisdictions. See, e.g., Miller v. Bargain City, U.S.A., Inc, 229 F. Supp. 33, 37 (E.D. Pa. 1964); Trussell v. United Underwriters, Ltd., 228 F. Supp. 757 (D. Colo. 1964); Brown v. Bullock, supra; Remar v. Clayton Securities Corp., 81 F. Supp. 1014 (D. Mass. 1949). The tort theory was recognized by the Supreme Court in Texas \& Pacific Ry. v. Rigsby, 241 U.S. 33, 39 (1916). Where privity of contract is present, however, the plaintiff apparently is able to base his right of action on section 29(b) of the 1934 Act, which provides that all contracts made "in violation" of any provision of the Act shall be voidable as to the rights of the violator. While this "contract theory" says nothing about the substantive misconduct which may constitute a violation of Rule $10 \mathrm{~b}-5$, it at least avoids the "willfülness" issued raised by section 32 and the "tort theory." See text accompanying notes 55-62 infra. But see Crist v. United Underwriters, Ltd., 343 F.2d 902 (10th Cir. 1965), where a contract theory of recovery was denied despite the presence of privity and the rescission remedy sought. "The origin of this cause of action shows it is in tort." Id. at 904.

19 SEC v. Capital Gains Research Bureau, Inc., 375 U.S. 180, 195 (1963), construing a 
Briefly, the federal securities legislation was designed to protect the investor, 20 maintain integrity and honesty in the securities market, ${ }^{21}$ and curb "unnecessary, unwise, and destructive speculation." 22 Where Congress expressly created civil liabilities to implement these policies, two aims predominated: to compensate the innocent investor who had lost money on falsely valued securities and to deter the proscribed practices by effective civil sanctions which complemented injunctive and criminal remedies. ${ }^{23}$ But Congress was not unmindful of the necessity

section of the Investment Advisers Act of 1940 (54 Stat. 847 (1940), 15 U.S.C. $\S 80 \mathrm{~b}-6$ (2)) which is almost identical to $10 \mathrm{~b}-5(3)$, to be a proper basis for injunctive action against the defendant investment adviser's undisclosed "scalping" practices, although no intent to injure clients or actual injury had been established. Cf. SEC v. C.M. Joiner Leasing Corp., 320 U.S. 344, 350-51 (1943).

20 See, e.g., H.R. REP. No. 1383, 73d Cong., 2d Sess. 5 (1934): "As a complex society so diffuses and differentiates the financial interests of the ordinary citizen that he has to trust others and cannot personally watch the managers of all his interests as one horse trader watches another, it becomes a condition of the very stability of that society that its rules of law and of business practice recognize and protect that ordinary citizen's dependent position." See also 78 CoNG. REc. 8040 (1934) (remarks of Rep. Rayburn); 78 CoNG. REC. 7717 (1934) (remarks of Rep. Ford); 78 CoNG. REc. 7861 (1934) (remarks of Rep. Lea-co-author of the House bill). Cf. 78 Cong. Rec. 7865 (1934) (remarks of Rep. Wolverton-co-author of the House bill). For a sweeping judicial view of this aim, see Surowitz v. Hilton Hotels Corp., 342 F.2d 596 (7th Gir. 1965) (dictum): "[T] he policy of the federal securities laws is to protect investors, including the uninformed, the ignorant and the gullible." Id. at 602. That such a view is overly broad is at least suggested by the remarks of Rep. Rayburn-co-sponsor of the 1933 Act-on the House floor: "Let me repeat that what we seek to attain by this enactment is to make available to the prospective purchaser, if he is wise enough to use it, all information that is pertinent that would put him on notice and on guard, and then let him beware." 77 Cong. REc. 2916 (1933)." (Emphasis added.)

21 Or, as it was expressed in the House Committee Report, "The bill seeks to give to investors markets where prices may be established by free and honest balancing of investment demand with investment supply." H.R. REP. No. 1383, 73d Cong., 2d Sess. 10 (1934). The Report also spoke in terms of an "extension of the legal conception of a fiduciary relationship-a guarantee of 'straight shooting'-[to support] . . . the constant extension of mutual confidence." $I d$. at 5.

22 H.R. REP. No. 1383, supra note 21, at 2. Note the Committee's reference to the Presidential Message of February 9, 1934, wherein President Roosevelt condemned the fact that "outside the field of legitimate investment naked speculation has been made far too alluring and far too easy for those who could and those who could not afford to gamble." Id. at 1. See also S. ReP. No. 792, 73d Cong., 2d Sess. 1 (1934); 78 Cong. Rec. 7689 (1934) (remarks of Rep. Sabath); 78 CoNG. REc. 7717 (1934) (remarks of Rep. Ford). All three broad goals may be viewed as summed up implicitly in Representative Rayburn's comments about the 1933 Act: "The purpose of this bill is to place owners of securities on a parity, so far as is possible, with the management of the corporations and to place the buyer on the same place so far as available information is concerned, with the seller." 77 Cong. REc. 2918 (1933).

23 See, e.g., S. REP. No. 792, 73d Cong., 2d Sess. 12 (1934): “Experience with State laws designed to prevent the exploitation of the investor ... has demonstrated the 
to avoid as far as possible any undue interference with honest business activity in the securities market. ${ }^{24}$

A particular source of legislative policy relevant to $10 \mathrm{~b}-5$ finds expression in section 12(2) of the Securities Act of 1933. ${ }^{25}$ The language of that section, strikingly similar to clause (2) of $10 \mathrm{~b}-5$, proscribes false or misleading statements made in connection with the sale of securities. ${ }^{26}$ Unlike 10b-5, however, section 12(2) creates a civil right of action only in favor of purchasers of stock. Moreover, the section 12(2) action is governed by expressly delineated substantive and procedural elements: for example, buyers alone can sue under the section, ${ }^{27}$ plaintiff and defendant must be in privity, ${ }^{28}$ the defendant-seller is liable for negligent as

inadequacy of criminal penalties as the sole sanction. Customers are ordinarily reluctant to resort to criminal proceedings, and in the absence of complaints by them, the discovery of violations is often impossible. Furthermore, if an investor has suffered loss by reason of illicit practices, it is equitable that he should be allowed to recover damages from the guilty party." See also H.R. ReP. No. 1383, 73d Cong., 2d Sess. 5 (1934); 78 Cong. REc. 7862 (1934) (remarks of Rep. Lea); 78 Conc. REc. 8040 (1934) (remarks of Rep. Rayburn); 78 CoNG. Rec. 8088 (1934) (remarks of Rep. Mapes). The civil liabilities provisions of the 1933 Act, notably section 12(2), reflect the same twofold approach of compensation and deterrence. See S. REP. No. 47, 73d Cong., Ist Sess. I (1933); H.R. REP. No. 85, 73d Cong., 1st Sess. 1-5 (1933).

24 See S. Rep. No. 792, 73d Cong., 2d Sess. I (1934); 78 Cong. Rec. 7934 (1934) (remarks of Rep. Kenney); 78 Conc. Rec. $8200,10185-86$ (1934) (remarks of Sen. Byrnes).

2548 Stat. 74 (1933), 15 U.S.C. 771 (2) (1958).

26 Section 12(2)'s prohibition covers "any person who offers or sells a security . . . , by the use of any means or instrumentality of transportation or communication in interstate commerce or of the mails, by means of a prospectus or oral communication, which includes an untrue statement of a material fact or omits to state a material fact necessary in order to make the statements made, in the light of the circumstances under which they were made, not misleading ...." The language of section $17 \mathrm{a}(2)$ of the 1933 Act (48 Stat. 74 (1933), 15 U.S.C. $77 q(a)(2)(1958)$ ) is almost identical to 12(2) and $10 \mathrm{~b}-5(2)$. In fact, $10 \mathrm{~b}-5$ was avowedly aimed at plugging the loophole in $17 \mathrm{a}$, which applies only to seller practices. SEC ANN. REP. 10 (1942). Whether section 17, a criminal provision, can serve as a basis for implied liability as does $10 \mathrm{~b}-5$ is apparently still an open question. While several cases have held that it could so serve, Dack v. Shanman, 227 F. Supp. 26 (S.D.N.Y. 1964); Pfeffer v. Cressaty, 223 F. Supp. 756 (S.D.N.Y. 1963), these cases involve no discussion of the reasons for such implication. Rather, they seem to assume that 17 a should be treated the same as $10 \mathrm{~b}-5$. However, the arguments against implication from section 17 seem much stronger than those involving 10b-5. See III Loss, Securities Regulation 1784-87 (2d ed. 1961). It has recently been advanced that section $12(2)$ provides a civil remedy for violation of $17 \mathrm{a}(2)$, which therefore cannot be an independent source of civil liability. Trussell v. United Underwriters, Ltd., 228 F. Supp. 757, 766-67 (D. Colo. 1964).

27 The only potential defendant is one who "offers or sells a security." 48 Stat. 74 (1933), I5 U.S.C. $77 l(2)$ (1958). But note section 15, which makes "controlling persons" liable to the same extent as the "controlled" seller, subject to a defense of "no knowledge of, or reasonable grounds to believe in" the liability-creating facts. 48 Stat. 74 (1933), as amended, 15 U.S.C. 770 (1958).

28 ". . . shall be liable to the person purchasing such security from him." 48 Stat. 74 (1933), 15 U.S.C. $77 l(2)$ (1958). See note 27 supra. 
well as knowing mis-statements, ${ }^{29}$ and the buyer need not prove his reliance on the mis-statement. ${ }^{30}$ The statute of limitation provides further restrictions by barring suits brought one year after the mis-statement was or should have been discovered, or in any case three years after the sale. ${ }^{31}$ Also, a plaintiff has a liberal venue option, 32 but he may be required to post a security bond. ${ }^{33}$

While the proscriptive language of $10 \mathrm{~b}-5(2)$ and section $12(2)$ is nearly identical, 10b-5(2) fails to specify the substantive and procedural elements of an action thereunder. The worry has been that any reading of 10b-5(2) more liberal than 12(2) for buyer-plaintiffs will effectively nullify the latter section. Yet to import the section 12(2) elements into 10b-5 seems utterly arbitrary in the way it would affect seller-plaintiffs: nor would a differentiation between buyer and seller which either precludes the former from suit or imports the section 12(2) elements as to him be acceptable, since $10 \mathrm{~b}-5$ on its face makes no such discrimination between buyer and seller. The dilemma posed for the courts is that to imply a buyer's civil action under $10 \mathrm{~b}-5(2)$ in the face of the pre-existing detailed expression of congressional concern in section 12(2) is either to limit the effectiveness of section $12(2)$ by creating a possibly more attractive alternative remedy, thereby ignoring express congressional intent, or to thwart whatever intent is discernible in $10 \mathrm{~b}-5$ by importing artificial distinctions or requirements into it. The obvious solution would be to recognize the anomaly and either refuse to imply a buyer's civil action under $10 \mathrm{~b}-5(2)^{34}$ or imply a buyer's action and delineate it by systematic analysis of relevant policies. The courts, with few exceptions, ${ }^{35}$

29 I.e., he is liable unless he can prove that "he did not know, and in the exercise of reasonable care could not have known, of such untruth or omission." 48 Stat. 74 (1933), 15 U.S.C. 771(2) (1958).

30 Plaintiff need only establish that he did not know, in fact, of the omission. Ibid. See Murphy v. Cady, 113 F.2d 988 (1st Cir. 1940).

3148 Stat. 74 (1933), as amended, 15 U.S.C. $77 \mathrm{~m}(1958)$.

32 He may sue in ". . . the district wherein the defendant is found or is an inhabitant or transacts business, or in the district where the offer or sale took place, if the defendant participates therein." 48 Stat. 74 (1933), 15 U.S.C. 77v(a) (1958).

3348 Stat. 74 (1933), as amended, 15 U.S.C. $77 \mathrm{k}(3)$ (1958). This threat, discretionary with the court, is neither idle nor de minimis. See, e.g., Dabney v. Alleghany Corp., 164 F. Supp. 28 (S.D.N.Y. 1958); Montague v. Electronic Corp. of America, 76 F. Supp. 933, 936 (S.D.N.Y. 1948) (both cases involved the imposition of a $\$ 15,000$ bond).

34 See, e.g., Rosenberg v. Globe Aircraft Corp., 80 F. Supp. 123, 124 (E.D. Pa. 1948).

35 See Rosenberg v. Globe Aircraft Corp., 80 F. Supp. 123 (E.D. Pa. 1948), where the buyer-plaintiff alleged misconduct clearly cognizable under the $1933 \mathrm{Act}$, and the court held the plaintiff's sole remedy was under that section. "No other interpretation can avoid making a completely incongruous piece of legislation out of the two statutes in question." Id. at 125. Accord, Montague v. Electronic Corp. of America, 76 F. Supp. 933 (S.D.N.Y. 1948). These two cases remain as the sole examples to date of a court's refusal to allow a buyer to sue under 10b-5 because of the express right of action in the 1933 
have rejected the first solution, but none have proceeded to the second analysis.

In addition to the over-all goals of securities regulation, the pervasive influence of common law and equity principles should be kept in mind. The concepts involved in the $10 \mathrm{~b}-5(2)$ suit, such as misrepresentation, negligence, and scienter, all come laden with their own common law connotations and "courts generally interpret statutes in the context of the common law."36

Act. While Rosenberg's conclusion has been rejected, explicitly or implicitly, by most courts, the reasoning that the two statutes should be read as internally consistent still commands judicial attention. See, e.g., Fischman v. Raytheon Mfg. Co., 188 F.2d 783 (2d Cir. 1951); Trussell v. United Underwriters, Ltd., 228 F. Supp. 757 (D. Colo. 1964). But see Dauphin Corp. v. Redwall Corp., 201 F. Supp. 466 (D. Del. 1962). See text accompanying note 48 infra.

36 Royal Air Properties, Inc. v. Smith, 312 F.2d 210, 213 (9th Cir. 1962), in which it was held that the traditional defenses of estoppel, waiver and laches are available in a 10b-5 action. Cf. Straley v. Universal Uranium \& Milling Corp., 289 F.2d 370 (9th Cir. 1961), holding that estoppel and waiver were available defenses in actions under the civil liabilities provision of the 1933 Act. It is submitted, however, that primary emphasis should not be placed on the common law. The argument for looking initially to the common law as an "analogue" for delineating $10 \mathrm{~b}-5$ is based (a) on the assumption that Congress and the SEC must have intended that terms such as "fraud" be interpreted in light of the common law, and (b) on the necessity for uniform development and application of the Rule. 74 YaLE L.J. 658, 666 (1965). Such an approach seems inconsistent, however, when it is realized that the substantive meaning of a term like "fraud" or the elements of a deceit action vary from jurisdiction to jurisdiction. See 74 YALE L.J. 658, 670-71, 683 \& n.95 (1965). Such substantive divergence may readily be observed in the varying state approaches to a "duty of disclosure" rule, embodied in at least three characterizations-"majority," "minority" and "special facts" doctrines. See generally Comment, 30 U. CHr. L. REv. 121 (1962); Note, 42 VA. L. REv. 537 (1956). To the extent that the substantive elements of a $10 \mathrm{~b}-5(2)$ action would depend on the application of differing state common law formulations, the desired goal of uniformity would be hampered, not aided. Cf. McClure v. Borne Chem. Co., 292 F.2d 824 (3d Cir. 1961): "[S]tate law will only control where that law will not cut across the federal interests receiving expression in the federal right sought to be enforced. ... It can be said fairly that the Securities Exchange Act, of which Sections $10(\mathrm{~b})$ and $29(\mathrm{~b})$ are- parts, constitutes far reaching federal substantive corporation law." Id. at 834 . Moreover, this assumption that congressional and administrative silence indicates an intent to use terms with their common law connotations, if carried to its logical end, would seem to preclude reference to broad policy goals inherent in securities legislation taken as a whole, at least where such goals conflict with common law principles. It seems more reasonable to conclude that Congress intended to vest authority in the SEC to delineate the broad terms "manipulative and deceptive," with primary reference to the broad policy goals of the legislation. The legislative history of the 1934 Act indicates that Congress intended to vest the SEG with "broad discretionary powers" to implement the policies of the Act. See, e.g., H.R. REP. No. 1383, 73d Cong., 2d Sess. 3 (1934); S. REp. No. 792, 73d Cong., 2d Sess. 2 (1934); 78 Cong. REc. 8113 (1934) (remarks of Rep. Rayburn). For judicial rejection of the contention that the grant of power in 10(b) should be restrictively viewed, see Ellis v. Carter, 291 F.2d 270, 274 (1961). See generally, I DAvis, ADMINISTRATIVE LAW TREATISE \$\$ 2.01-2.16 (1958). Therefore, overall legislative policy rather than the common law should be the initial reference point. This, of course, should not preclude attempts to harmonize the resultant formulation 


\section{Absolute Liability}

Clause (2) does not mention knowledge or intent. On its face, the clause prohibits the bare making of a mis-statement. The first approach which it suggests, then, is absolute liability. Such an approach would compensate the investor who has lost money on falsely valued securities, one of the prime purposes of the "anti-fraud" provisions. ${ }^{37}$ Thus, it seems reasonable to conclude, as has one district court, ${ }^{38}$ that the defendant's state of mind is immaterial, for "the results are the same" to the plaintiff whether or not the defendant knew of the misrepresentation and intended to profit from it. Further, where plaintiff and defendant are in privity, recovery by the plaintiff results in a restoration of the status quo ante. Indeed, in many jurisdictions, it is accepted equity doctrine that innocent misrepresentations of material fact by a vendor, relied upon to the detriment of his vendee, can negate the transaction and support the vendee's action for damages. ${ }^{39}$ This doctrine, however, has not extended to statements which are not false in themselves but are merely misleading in context. Since 10b-5(2) includes misleading as well as false statements, reasoning by analogy to the common law appears unsatisfactory, although when privity exists and false statements are at issue the absolute liability approach may be harmonious with the common law.

Where plaintiff and defendant are not in privity, questions of restoring a status quo ante or of correcting the defendant's wrongful retention of plaintiff's money do not necessarily arise. Absolute liability may be justified as compensating injured plaintiffs. ${ }^{40}$ However, since most people

with one or more common law doctrines as assayed, e.g., in 74 YALE L.J. 658 (1965) and 30 U. CHI. L. REv. 121 (1962), nor should it preclude reference to traditional legal and equitable principles where legislative policy does not point in a discernible direction. See, e.g., Royal Air Properties, Inc. v. Smith, supra. But see McClure v. Borne Chemical Co., supra (although there is no clear legislative policy favoring or condemning the requirement of a security bond under $10 \mathrm{~b}-5$, state statutes demanding such a requirement are not applicable).

37 See note 23 supra.

38 Texas Continental Life Ins. Co. v. Bankers Bond Co., 187 F. Supp. 14 (W.D. Ky. 1960), rev'd on fact issue sub nom. Texas Continental Life Ins. Co. v. Dunne, 307 F.2d 242 (6th Cir. 1962).

39 See, e.g., Stein v. Treger, 182 F.2d 696 (D.C. Cir. 1950) (“One may honestly make a false representation, believing it to be true, but if made as a statement of fact, it is false and fraudulent." Id. at 698-99); Nocatee Fruit Co. v. Fosgate, 12 F.2d 250 (5th Cir. 1926) ("The affirmation of what one does not know or believe to be true is equally in morals and law as unjustifiable as the affirmation of what is known to be positively false. And even if a party innocently misrepresents a fact by mistake, it is equally conclusive, because it operates as a surprise and imposition on the other party, and misleads the parties contracting, on the subject of the contract." $I d$. at 252.) See generally WuLLISTON, ConTrACTs § 1500 (1936).

$40 \mathrm{It}$ is assumed that the deterrent factor of civil liability is inapplicable where, by hypothesis, the conduct involved is inadvertent. Thus, from the viewpoint of legislative 
who buy and sell stocks are investors, the defendants as well as the plaintiffs probably will be investors whom the securities legislation is intended to protect. The absolute liability approach would result, therefore, in the compensation of innocent investors by innocent investors. ${ }^{41}$ Moreover, absent privity, equity and common law principles run counter to the absolute liability approach; a loss is generally not shifted in the absence of causative "fault," which is lacking here by hypothesis. ${ }^{42}$ There is also a serious question regarding the effects an absolute liability approach would have on the general field of securities transactions. Such an approach at worst would encourage speculation and at best emasculate the principle of finality of agreement. Investors could transact with the thought that if the stock were not to fare well, some prior inadvertent mis-statement or omission by the other party to the contract might be unearthed, and the sale rescinded or damages paid. ${ }^{43}$ There would also be an in terrorem effect on the conscientious investor; the only sure way to be secure from the threat of future suits by unscrupulous or disgruntled buyers or sellers would be to refrain from investing at all.44

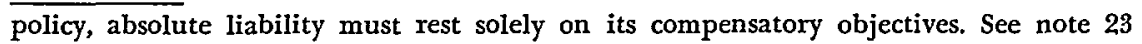
supra.

41 A notable exception occurs where the defendant is an issuer of securities. Absolute liability here would not result in such an anomaly-in fact, faultless liability would appear to be in accord with the policy of section $11 \mathrm{~b}$ of the 1933 Act, which leaves the issuer (as distinguished, e.g., from a director or accountant) no defense of good faith and reasonable investigation once a registration statement is shown to have been false or misleading. 48 Stat. 74 (1933), as amended, 15 U.S.C. 77k(b) (1958). Given that the same conduct may be actionable under Section 11 and Rule 10b-5, it is arguable that an extra proof burden on the plaintiff under the latter would defeat the purpose of the former. The argument is of little moment, however, since the plaintiff may still utilize section 11. This is not to say that the issuer-defendant under $10 \mathrm{~b}-5$ may not be under a higher duty than the investor-defendant. To the extent that an issuer may be held to a greater duty of care vis-à-vis the plaintiff under 10b-5(2), the broad policy in section 11 will not be neglected. See discussion of negligence liability in text accompanying notes 62-77 infra.

42 Holmes, The Common Law, 77-82, 88-96 (1881). It should be noted of course that the fault principle in the field of torts is not absolute in its operation. The courts have carved out exceptions to this principle, e.g., in so-called "dangerous instrumentality" situations, Rylands v. Fletcher, L.R. 3, H.L. 330 (1868), or in the area of defamation, imposing in these areas absolute liability. The fact that the common law generally demands the demonstration of fault before shifting a loss is thus not necessarily determinative of the question at hand. Nevertheless, it can be confidently stated that even if absolute liability under clause (2) is rejected purely for practical reasons, such rejection is entirely in accord with generally accepted common law tort principles. See 74 YALE L.J. 658, 689-90 \& n.118 (1965).

43 Such encouragement of speculation would run counter to one of the objectives of the 1934 Act. See note 22 supra. Moreover, even conceding that Congress did not intend to condemn a given form of speculation is not tantamount to finding a congressional policy of encouragement.

44 This is the suggestion of the SEC regarding those with access to inside information of a corporation. A party with inside information who wishes to avoid civil liability 
Thus, the absolute liability approach could well foster excessive speculation in the market by insuring the speculator against ordinary investment losses or, conversely, place an unhealthy restriction on the volume of securities transactions by imposing onerous burdens on good-faith investors. Whatever theoretical arguments may appear to favor absolute liability pale in the face of the serious practical consequences such a policy forebodes. Such an approach would retard, rather than effectuate, the goals of securities regulation. ${ }^{45}$

\section{INTENTIONAL Liability}

The most serious argument which will have to be met by the plaintiff seeking a broad interpretation of $10 \mathrm{~b}-5(2)$ is that some form of intent to misrepresent must be proven. Such an approach draws some strength from common law principles in that proof of scienter is generally required in an action for deceit. ${ }^{46}$ Moreover, the overall goals and policies of securities legislation would apparently not be hindered by such an approach, nor would specific liability provisions of the 1933 Act be contradicted.

However, the strongest arguments for an intent standard derive not from these factors but from the desire not to nullify section 12(2) judicially and from the tort theory of implication. Some courts have feared that if recovery is allowed to a buyer under $10 \mathrm{~b}-5(2)$ on the basis of negligent mis-statements, section 12(2) would become, in effect, a nullity. ${ }^{47}$

may choose either to disclose fully that information to the other party to the transaction or to refrain completely from dealing in that corporation's securities. See In re Cady, Roberts \&. Co., 40 S.E.C. 907 (1961). Under the absolute liability approach, even this very limited "choice" is not open to the investor, since he is by hypothesis not privy to any inside information and thus has no advance notice of what securities in which he should refrain from trading.

45 Apart from the suggestion of the district court in Texas Continental Life Ins. Co. v. Bankers Bond Co., 187 F. Supp. 14 (W.D. Ky. 1960), rev'd on fact issue sub nom. Texas Continental Life Ins. Co. v. Dunne, 307 F.2d 242 (6th Cir. 1962), that even an honest mistake will subject a defendant to civil liability under $10 \mathrm{~b}-5$, no court has held that liability will attach under $10 \mathrm{~b}-5$ for non-negligent misrepresentations, although the language of the courts is often far from clear. See, e.g., Royal Air Properties, Inc. v. Smith, 312 F.2d 210, 212 (9th Cir. 1962); Dack v. Shanman, 227 F. Supp. 26 (S.D.N.Y. 1964). Professor Loss suggests that the congressional delegation of power in section $10(b)$ is, by its terms, restricted to violations involving some form of knowledge or intent, as suggested by the words "manipulative or deceptive." III Loss, SECuRITIES REgulation 1767 (2d ed. 196I). See Trussell v. United Underwriters, Ltd., 228 F. Supp. 757 (D. Colo. 1964). Contra, Ellis v. Carter, 291 F.2d 270, 274 (9th Cir. 1961).

46 Such proof does not always entail demonstration of actual knowledge by the defendant. See, e.g., the broad alternate definitions of scienter in Boysen v. Petersen, 203 Ia. 1073, 211 N.W. 894 (1927) ("Scienter is now concededly held to have a broader meaning than actual knowledge of falsity."); WuLlston, CoNTRACTS $\S 1509$ (1936). See note 15 supra.

47 See Fischman v. Raytheon Mfg. Co., 188 F.2d 783 (2d Cir. 1951); Trussell v. United Underwriters, Ltd., 228 F. Supp. 757 (D. Colo. 1964). 
One escape which the courts have sought from the Scylla of nullifying section $12(2)$ and the Charbydis of judicially rewriting $10 \mathrm{~b}-5$ by reading the procedural requirements of section 12(2) into it is to "balance" the advantages and disadvantages ${ }^{48}$ in the $12(2)$ action and construe congressional intent to demand that the given advantages of the 12(2) action be extended to the buyer suing under 10b-5(2) only where they are accompanied or balanced by relevant disadvantages. Since the disadvantages (generally the procedural provisions) of the section 12(2) action cannot be read into the $10 \mathrm{~b}-5$ (2) action, ${ }^{40}$ this approach argues that the buyer cannot sue under the 1934 Act unless a new balance is struck, and new disadvantages are added to his action by way of an increased burden of proof of such substantive elements as scienter or reliance. It should be noted that because the balancing approach would not apply to seller-plaintiffs, who have no section 12(2) right of action, there is inherent in this scheme the possibility of making recovery under 10b-5 easier for seller-plaintiffs than for buyer-plaintiffs. Yet the plain language of the Rule calls for no such discrimination.

The central problem with the balancing approach is that there appear scant rational grounds for assigning relative weights to the particular elements balanced. Crudely stated, the balancing approach produces the equation: venue plus security for costs plus statute of limitations equal burden of proof of scienter and reliance. Who can tell whether the scienter or reliance element alone is sufficient to balance the removal of the procedural restrictions? The result under this quasi-algebraic exercise seems, therefore, somewhat arbitrary. But the concern this approach expresses with allowing the-buyer's section $12(2)$ remedy to remain in effect as a practical implementation of the will of Congress seems wise. Obviously, if $10 \mathrm{~b}-5(2)$ is construed to parallel exactly the

48 See notes 25-34 supra, and accompanying text.

49 The reasons for not imposing the restrictions of the section 12(2) action on the $10 \mathrm{~b}-5(2)$ proceedings may be summarized as follows: Venue-section 27 of the 1934 Act establishes venue provisions governing all actions brought under the 1934 Act. 48 Stat. 881 (1934), 15 U.S.C. \& 78aa (1958); Statute of Limitations-where the 1934 Act provides any statutes of limitation, they refer to particular sections of the bill. There is no general or catch-all statute of limitations in the bill. And, since no limitation period is prescribed in Rule 10b-5 itself, the applicable statute for actions at law under 10b-5 has been held to be that of the forum state. See, e.g., Fratt v. Robinson, 203 F.2d 627 (9th Cir. 1953); Premier Indus., Inc. v. Delaware Valley Fin. Corp., 185 F. Supp. 694 (E.D. Pa. 1960); Northern Trust Co. v. Essaness Theatres Corp., 103 F. Supp. 954 (N.D. Ill. 1952); Osborne v. Mallory, 86 F. Supp. 869 (S.D.N.Y. 1949). Where the action is of an equitable nature, the federal equity principle of laches will be applicable. Royal Air Properties, Inc. v. Smith, 312 F.2d 210 (9th Cir. 1962). Cf. Holmberg v. Arbrecht, 327 U.S. 392 (1946); Undertaking for Costs-the 1934 Act has no catch-all requirement applicable to all actions and section $10(\mathrm{~b})$ does not mention such a requirement. See McClure v. Borne Chem. Co., 292 F.2d 824 (3rd Cir. 1961). 
remedy given the buyer in section 12(2) without the latter's more restrictive procedural provisions, the 1933 civil remedy is effectively nullified, for no buyer-plaintiff would utilize it. This would mean the courts prefer an implied to an express statutory remedy-an impossible conclusion. Since this judicial nullification is to be avoided, the validity of balancing lies in its suggestion that the $10 \mathrm{~b}-5$ civil action must differ somehow from the 12(2) action.

In Ellis v. Carter ${ }^{50}$ the Ninth Gircuit rejected the balancing approach because the plain wording of section $10(b)$ and the Rule, referring to the "purchase or sale" of securities, demands that buyers and sellers be treated equally. This reasoning appears correct. Since that court rejected a scienter standard for $10 \mathrm{~b}-5,51$ the danger of nullifying $12(2)$ was readily apparent. But the court thought the beneficial results of its decision justified the danger. Weight would be given to the apparently dominant policy of Congress "to provide complete and effective sanctions, public and private, in respect to duties and obligations imposed under the two acts," and no procedural distinctions between buyer and seller would be made, "no reason appearing why Congress would have wanted the procedures to be different." This approach also avoids the Charbydis of judicially rewriting the 1934 Act and permits the most recent enactment to govern. 52

The second argument for the intentional liability standard derives from the tort theory by which civil liability is inferred when no privity between plaintiff and defendant exists. ${ }^{53}$ Under this theory only the violation of a criminal statute creates civil liability in the violator. But $10 \mathrm{~b}-5$ is not itself a criminal enactment; violation of the Rule, like violation of any section of the 1934 Act, becomes criminal only when the violation is willful, as provided by section 32.54 Since a plaintiff must establish a criminal violation to support private recovery, therefore, he must establish the defendant's "willfulness." This was the position taken by Judge Lumbard in his concurring opinion in Spirt $v$. Bechtel, ${ }^{55}$ where the plaintiff unsuccessfully tried to hold the defendant civilly liable

50291 F.2d 270 (9th Cir. 1961). See also Matheson v. Armbrust, 284 F.2d 670 (9th Cir. 1960).

51 Ellis v. Carter, 291 F.2d 270, 274 (9th Cir. 1961).

52 In effect, the Ninth Circuit was echoing Professor Loss's comment on the nature of the securities acts, viz. that our system of federal securities regulation "after all is not an integrated code adopted at a single sitting, however one may try to construe it so." III Loss, Securities Regulation 1790 (2d ed. 1961).

53 See note 17 supra. The tort theory may also be utilized where privity exists, but in such a situation the contract theory based on section 29(b) of the 1934 Act eliminates the "willfulness" problem.

5448 Stat. 881 (1934), as amended, 15 U.S.C. $78 \mathrm{ff}$ (1958).

55232 F.2d 241 (2d Cir. 1956). 
for violation of the Merchant Marine Act. The provision involved, like section $10(b)$, did not mention civil or criminal liability, but another section of the Act, analogous to section 32 of the 1934 Act, provided that willful violation of the substantive section was criminally punishable. Judge Lumbard argued that "since the acts here are only criminal if they were 'willfully' performed and it is doubtful that there was any willfulness, there should be neither criminal nor civil responsibility." 56 However, as Judge Frank pointed out in dissent, the term "willful" is subject to numerous constructions of varying degrees of severity. Indeed the Supreme Court ${ }^{57}$ has indicated several interpretations of "willful," as used in criminal statutes, any one of which might be proper depend. ing on "the context in which it is used." 58 These include acts done “... without justifiable excuse, . . . stubbornly, obstinately, perversely ... without ground for believing it is lawful, . . . or conduct marked by careless disregard whether or not one has the right so to act."59 Where a defendant has made a statement, the misleading quality or falsity of which was unknown to him but which could have been ascertained by the exercise of some care, his failure to verify the statements might be characterized as a "careless disregard" of the listener. Thus under appropriate circumstances, willfulness might be simply an alternative way of describing a negligence standard. ${ }^{60}$ When circumstances are appropriate should depend on the policies of the securities legislation. Decisions in this area are unclear due to the practice of framing

56 Id. at 251.

57 United States v. Murdock, 290 U.S. 389 (1933).

58 Id. at 395 .

59 Id. at 394-95 (citations omitted).

60 Generally, a broad construction of securities legislation is preferred to a narrower one where a choice is presented. SEC v. Capital Gains Research Bureau, Inc., 375 U.S. 180 (1963); SEC v. C.M. Joiner Leasing Corp., 320 U.S. 344, 353-55 (1943). Moreover, the courts' past treatment of a willfulness requirement, for instance in broker license revocation actions under the 1934 Act, suggests that this element is not to be construed rigorously. See, e.g., Tager v. SEC, 344 F.2d 5, 8 (2d Cir. 1965) (“' [W]illfully' . . . means intentionally committing the act which constitutes the violation. There is no requirement that the actor also be aware that he is violating one of the Rules or Acts."); Hughes v. SEC, 174 F.2d 969 (D.C. Cir. 1949) (defendant's refusal to cease certain practices at the request of the SEC satisfied the "willful" requirement in spite of her assumedly bona fide belief that her conduct was lawful); Norris \& Hirshberg, Inc. v. SEC, 177 F.2d 228 (D.C. Cir. 1949) ("willful" element satisfied by "conscious, knowing and purposeful course of action"). Cf. United States v. Benjamin, 328 F.2d 854, 863 (2d Cir. 1964); Dennis v. United States, 171 F.2d 986, 990 (D.C. Cir. 1948); NLRB v. Erie Resistor Corp., 373 U.S. 221, 227-29 (1963); Stone v. United States, 113 F.2d 70, 75 (6th Cir. 1940); United States v. Schaefer, 299 F.2d 625, 629 (7th Cir. 1962) (criminal violation of section 17a of 1933 Act upheld despite fact that defendant was unaware of the falsity of his statements). See also Note, 63 Mrck. L. REv. 1070, 1080 (1965) (equating the "modern concept of scienter" with negligence). 
complaints in terms of intent.61 In both the privity and non-privity cases, therefore, whether an intentional or negligence standard should obtain must be decided with reference to the policies involved, and not to the theory of implying liabilities, although, because of the willful requirement, something more than simple negligence may be required in the non-privity situation. This comment seeks to define a negligence standard which should satisfy this requirement.

\section{Negligence Liability}

While absolute liability advances the compensatory objectives of the Act, its use might unduly hamper legitimate business activity in the securities field because of the possibility of frivolous suits in fluctuating market periods. On the other hand, while an intent requirement for liability would probably not thwart the goals of the securities legislation, it would also not further those goals effectively. It is the thesis of this comment that a negligence standard best effectuates these goalsprotection of the investor, maintaining open and honest dealing, and equalizing access to information between buyer and seller of securities. ${ }^{62}$ Indeed, section 12(2) suggests that a negligence standard for securities transactions is most compatible with probable congressional intent. Not only was the legislative choice there made in favor of the less severe degree of culpability, but by shifting the burden of proof to the defendant Congress imposed a presumption of such culpability against the defendant. ${ }^{63}$ Under section 12(2) recovery is allowed against the seller unless he can establish "that he did not know and in the exercise of reasonable care could not have known, of such untruth or omission." 64

61 Several courts have referred to the necessity of proving "fraud" (Fischman v. Raytheon Mfg. Co., 188 F.2d 783 (2d Cir. 1951)) or "some form" of scienter (Trussell v. United Underwriters, Ltd., 228 F. Supp. 757 (D. Colo. 1964)) to support recovery, and have held that this would entail a greater burden of proof than is demanded by section 12(2). In Trussell, supra, and in Thiele v. Shields, 131 F. Supp. 416 (S.D.N.Y. 1955), the courts clearly distinguished between negligent mis-statements, considered not actionable under $10 \mathrm{~b}-5$, and intentional mis-statements. However, in most cases dealing with $10 \mathrm{~b}-5$ actions, the complaints have apparently been framed in terms of intent or knowledge, probably to be most secure in an uncharted area of law. See Latty, Aggrieved Shareholders Under the S.E.C. Statutes, 18 LAw \& CONTEMP. ProB. 505, 526 (1953).

62 See note 22 supra (remarks of Rep. Rayburn).

63 The objection has been raised that there is "no rational reason" to look to one section of the acts over another as a "model" for fashioning the 10b-5 remedy. Comment, 74 YALE L.J. 658, 666 (1965). This may be true as regards clauses (1) and (3), to the extent that their language is not similar to that of any express civil liability provision. Clause (2) and section 12(2), however, are virtually identical in their description of activity proscribed. For this reason alone, the legislative approach to misrepresentation taken in section 12(2) should be applicable to $10 \mathrm{~b}-5(2)$ misrepresentation actions, subject to the caveat of the Fischman-Trussell analysis. See text accompanying notes 48 51 supra.

64 See note 30 supra. 
Congress's concern in section 12(2) was to place the duty of care on the party with greater access to relevant information. ${ }^{65}$ The purpose of the shifted burden of proof was to implement the congressional judgment that sellers were generally in a better position to discover material information about the security involved.66 While this may be true in the case of an issuer of a security, once the issue is launched into the market, the assumption underlying section 12(2)'s one-sided cause of action does not seem compelling. Thus, the seller of the stock may well be a minority shareholder and the buyer a majority shareholder or director of the corporation. In such a case it is clearly unjustifiable to assume that the seller is better able than the buyer to discover the "prospective earnings and business plans" of the corporation. ${ }^{67}$ The concern over access to relevant information as a standard of care would seem applicable to 10b-5(2), but without the judgment that sellers alone should observe the standard. Similarly, the burden of proving access should remain on the plaintiff, since no judgment as to whether buyers or sellers generally have access can be made.

This congressional concern with placing responsibility on the party having greater access to material information has been acknowledged in cases involving complete non-disclosure under $10 \mathrm{~b}-5(3) \cdot{ }^{68}$ Liability in such cases is based on a breach of duty owed by the defendant to the plaintiff - the duty to disclose. Although this obligation has been characterized as "fiduciary" or "quasi-fiduciary," the duty to disclose under 10b-5(3) does not depend on the traditionally delineated relationship. Rather, the obligation can arise in isolated sales transactions between total strangers, linked only as buyer and seller. ${ }^{69}$ The primary factor which

65 See, e.g., remarks of Rep. Rayburn, supra note 22. It has been suggested that the policy is in fact narrower in that the duty of care (negligence liability) was imposed only as regards those "statements made in business transactions which yield . . . [the speaker] economic benefit." Comment, 74 YAlE L.J. 658, 686 (1965). As far as section 12(2) is concerned, since privity is required, assumedly every defendant will fit this category, though even here the effect of section 15 might raise a question as to the suggested limit. Assuming that the privity restriction, like the buyer-plaintiff restriction, is not to be carried over to lob-5, the direct applicability of the "economic benefit" rationale seems unnecessary.

66 See H.R. REP. No. 85, 73d Cong., 1st Sess. 23-24 (1933). The Supreme Court explained the general approach of the 1933 act thusly: "[I]t is clear that the Securities Act was drafted with an eye to the disadvantages under which buyers labor. Issuers of and dealers in securities have better opportunities to investigate and appraise the prospective earnings and business plans affecting securities than buyers. It is therefore reasonable for Congress to put buyers of securities covered by that Act on a different basis from other purchasers." Wilko v. Swan, 346 U.S. 427, 435 (1953).

67 See note 66 supra.

68 See note 9 supra.

69 Indeed, in In re Cady, Roberts \& Co., 40 S.E.C. 707 (1961), the defendant probably did not see or know the identity of the seller of the stock, since the transaction occurred on the exchange. 
gives rise to the duty is the unequal access to material information. Thus, where one party, buyer or seller, is in possession of inside corporate information to which the other party does not have access, 10b-5(3) probably requires disclosure. ${ }^{70}$ It is not the defendant's position as insider per se which imposes the duty on him, but rather the possession of material facts to which the other party has no access. Thus, even where the defendant is an "insider," such as a director of the corporation, it has been held that his failure to disclose material facts to the plaintiff will not lead to liability where the plaintiff himself has the ability and opportunity to discover those facts easily. ${ }^{71}$ On the other hand, given the defendant's possession of inside information to which the plaintiff does not have access, liability for non-disclosure is possible under clause (3) even where defendant is not, technically speaking, an insider. ${ }^{2}$

Such application of clause (3) clearly illustrates an implicit recognition of the broad congressional goal of equalization of access, reflected in section $12(2)$ of the 1933 Act. The duty of disclosure under clause (3) further operates to preserve the integrity of securities transactions - a primary aim of federal securities legislation-by promoting candor in discussion and mutual confidence and respect between the parties to a transaction. Clearly, speculation is curbed-a further goal of Congress-to the extent that quick turn-overs on the basis of "hot tips" are discouraged. These policies and arguments apply similarly to 10b-5(2). The general congressional scheme is apparent and the access to information standard emerges as central to the duty of care under 10b-5(2).

Although section 12(2) does not require proof of reliance-the plaintiff need show only his own lack of actual knowledge and the fact that the mis-statement was made-the inclusion of a reasonable reliance element in 10b-5(2) actions would be desirable, if not necessary. ${ }^{73}$ Such an element

70 Such non-disclosure forms the basis for the SEC's complaint against the Texas Gulf Sulphur Company, soon to be litigated in the Southern District of New York. N.Y. Times, April 21, 1965, \& C, p. 63, col. 4.

71 Kohler v. Kohler Co., 319 F.2d 634 (7th Cir. 1962).

72 In re Cady, Roberts \& Co., 40 S.E.C. 907 (1961). See note 9 supra.

73 Although, as Professor Loss points out, inclusion of a reliance element is still an open question, III Loss, SEcurrTies Regulation 1766 (2d ed. 1961), most courts seem to have decided, implicitly or explicitly, that reliance is necessary for recovery. See, e.g., Trussell v. United Underwriters, Ltd., 228 F. Supp. 757 (D. Colo. 1964); List v. Fashion Park, Inc., 227 F. Supp. 906, 914 (S.D.N.Y. 1964) ("[T]he element of reliance has not been read out of [section] 10(b) and [Rule] . . . 10b-5."), aff'd, 340 F.2d 457 (2d Cir. 1965); Carr v. Warner, 137 F. Supp. 611, 613 (D. Mass. 1955) (dictum); Nash v. J. Arthur Warner \& Co., 137 F. Supp. 615, 618 (D. Mass. 1955) (dictum); Mills v. Sarjem Corp., 133 F. Supp. 753, 768 (D.N.J. 1955). It has been advanced that reliance is but a subcategory of causation, i.e., that in certain circumstances, it would be unjust to deny recovery to a plaintiff who could show that defendant's conduct caused plaintiff's injury but not reliance. Comment, 74 YALE L.J. 658, 671-72, 685 (1965). Such an approach seems sound, although it must be noted that a causation requirement is much more difficult to prove in light of the myriad intervening, independent causes which could 
limits the class of investors who will be protected under $10 \mathrm{~b}-5(2)$ to conscientious buyers and sellers in good faith. These are the parties that the legislation most properly seeks to protect. ${ }^{74}$ Not only should the plaintiff have to prove that he relied on the defendant's statements, but he must convince the trier of fact that his reliance was reasonable under all the circumstances at the time. In this way recovery would be denied to those who, because of their "business sophistication," acumen, or ready access to the information involved, ${ }^{75}$ could reasonably be expected to exercise a higher degree of care and investigation in their dealings.

While the proposed duty of care under $10 \mathrm{~b}-5(2)$ is akin to a "fiduciary" or "quasi-fiduciary" duty, it can be said to resemble more the common law duty to refrain from positive actions which entail a substantial risk of harming others, if it is conceded that financial harm from negligently used words is potentially as great, if not greater, than, for example, harm from negligently driven automobiles. The key factor is the risk of harm to others when the speaker has greater access to relevant information, and the proposed duty should be delineated by this concept. Thus, the speaker's duty to investigate should arise only where it is reasonable to expect him to foresee that his representations, if false or misleading, might damage the innocent investor. This limitation is suggested by reference to negligence theory, for the foreseeability of the resultant harm is a concept basic to the common law negligence action. ${ }^{76}$ Its

have affected the price of the security in question. See, e.g., Comment, 32 TExas L. REv. 197, 210 n.47 (1953). For congressional recognition of this burden in relation to the 1933 Act, see H.R. REP. No. 85, 73 d Cong., 1st Sess. 3 (1933).

74 See authorities cited supra note 20; cf. authorities cited supra note 24. See also Royal Air Properties, Inc. v. Smith, 312 F.2d 210, 213-14 (9th Cir. 1962).

75 Cf. Kohler v. Kohler Co., 208 F. Supp. 808 (E.D. Wis.), aff'd, 319 F.2d 634, 641-42 (7th Cir. 1962), where the court said: "[H] the actual and normal business acumen of the seller [plaintiff]. Here the company could fairly deal with [the plaintiff] ... in a manner that might not be fair if the plaintiff had been a novice to stock transactions or the corporation's activities." In List v. Fashion Park, Inc., 227 F. Supp. 906 (S.D.N.Y. 1964), aff'd, 340 F.2d 457 (2d Cir. 1965), recovery was denied because the plaintiff failed to prove, inter alia, reasonable reliance on the alleged complete omissions of the defendants. The district court pointed out that it knew of no one possessing "greater business sophistication" than the renowned plaintiff, but the circuit court disapproved of this broad approach, stating that "sophistication or naivete" should not be a per se bar to recovery: "The proper test is whether the plaintiff would have been influenced to act differently than he did act if the defendant had disclosed to him the undisclosed fact." 340 F.2d at 463. Citing Kohler, supra, the court agreed that the "materiality" of a fact could well depend on the abilities and opportunities of the plaintiff such that disclosure of the given data "would have been of little or no concern to him." Id. at 464.

76 See, e.g., Palsgraf v. Long Island R.R., 248 N.Y. 339, 343-45, 162 N.E. 99, 100-01 (1928) (Cardozo, C. J.): "The risk reasonably to be perceived defines the duty to be obeyed. ... If the harm was not willful, he must show that the act as to him had possibilities of danger so many and apparent as to entitle him to be protected against the doing of it though the harm was unintended." 
primary value for $10 \mathrm{~b}-5(2)$ actions is in non-privity cases; a foreseeability test serves to limit the in terrorem effect of the civil action on good faith investors by assuring them that, at least under some circumstances, they need not check every statement they make to ensure it is not false or misleading. Thus, a director making statements to other directors of the same corporation might reasonably assume that his listeners are themselves aware of the facts he is stating or are at any rate capable of checking them themselves, and that his statements are not likely to lead his listeners to actionable financial detriment. But the same statements made to an average investor foreseeably could cause the latter to act upon them. In such a case, because of the director's special access to information which is unavailable to his listener, it is incumbent upon him to make accurate and non-misleading statements within the limits of his access to the pertinent information.

If an insider or experienced trader misrepresents with the qualification that it is only his opinion or if he identifies the source of the statement should he still be expected to check its completeness and veracity? Here again, the key seems to be the foreseeability of the harm and the reasonableness of the plaintiff's alleged reliance on the statement. Obviously an experienced trader of securities should realize that his opinion may carry great weight with a novice to the field and that, despite verbal qualification, his statements might quite conceivably influence the investor's action. In such a case, it would be incumbent on the speaker to act reasonably to forestall foreseeable harm. ${ }^{77}$

77 A further limitation on the duty of care was suggested in Comment, 74 YAlE L.J. 658 (1965), where it was said that the duty of diligence and investigation should be imposed only where statements are made in the course of an "economically motivated" transaction. Id. at 687 . As an example, the author posits a negligently prepared market letter distributed by broker-dealer $A$, relied upon by Investor $I$, who buys to his detriment from broker-dealer $B$. $A$ should be liable, the comment maintains, only if the letter was distributed "with the object of maintaining or establishing business associations." Ibid. In this case, $A$ would probably be liable since it is to the firm's benefit that even investors who are not immediately potential buyers become acquainted with $A$ 's services. Ibid. The difficulty with this approach is the problem of line-drawing. Unless a per se rule were established that any material statements by a firm or individual engaged in commercial activities is necessarily "economically motivated," the courts would be faced with the Herculean task of examining the ultimate moving force behind each defendant's statements. The Yale comment distinguishes from the market letter example the case of negligently overblown statements of earnings by a corporation, which thereafter neither buys nor sells its own securities. Such statements might be beneficial to the corporation's "public image" but not to its business activities "in the same manner" that the market letter assists the broker-dealer's business. Id. at 688. This distinction would not appear to be one upon which a comprehensive and definitive formulation of liability can be structured. Rather, it is preferable to consider "economic motivation" as an element sufficient but not necessary in establishing the foreseeability of harm. In short, the "economic motivation" criterion, if viewed broadly, adds little to the delineation of the scope of liability; if viewed strictly, this criterion would seem to create unnecessary and burdensome difficulties of proof. 


\section{CONCLUSION}

A negligence standard based on the concept of access to information should obtain in 10b-5(2) actions. Reasonable reliance on the statements made should be required, and the burden of proving these elements should remain on the plaintiff. What is negligent and what is reasonable should depend in each case on the circumstances involved, so that each party will be charged with the responsibility of his own knowledge, experience, position and reputation. Lack of privity of contract should not be a determinative factor where the requisite negligence, foreseeability, and causal effect is established. Such a scheme of recovery should serve both compensatory and deterrent goals of civil liability by encouraging honesty, competence and stability in the securities market without unduly hampering the operations of the conscientious investor. And, finally, such a negligence formula should harmonize the operation of the express civil liability provision of section 12(2) with the implied civil liability of $10 \mathrm{~b}-5$. 